(1921 and earlier editions). Although Rosenbusch and Zirkel adhered to Steininger's spelling, K. A. Lossen (Zeit. Deutch. Geol. Ges., 1898, p. 258) did not, preferring " tholeyite"-likewise the choice of M. Schuster (Geog. Jahresheft, xxvi, 1914, p. 242) and of G. Fischer as late as 1951 (Geol. Rundschau, xxxix, 59). J. W. Judd (Quart. Jour. Geol. Soc., xlvi, 1890, p. 379) chose " tholeite", as did the editor of the Summary Rep. of Progr., Geol. Surv. of Great Britain (1912 and 1913) and also H. S. Washington (Prof. Paper, U.S. Geol. Surv., No. 99, 1917). Incidentally it may be remarked that there is no obvious objection to eliding the first " $i$ " in Steininger's word, if in future it should prove useful to students of rock-types, magmatypes, and the origin of basaltic melts.

The second reason for concern has to do with pronunciation-a trouble only partly lessened if " tholeyite" or " tholeite" were to be adopted for general use. I have not discovered any of the competing names in the New Oxford or any other complete British dictionary. "Tholeiite" does appear in the 1949 edition of Webster's New International Dictionary, published in the United States. There the proper pronunciation is given as " Tó'-li-it ", the editor evidently remembering that in German the " $h$ " of the digraph " $t$ " " is silent. Thus there is some difficulty of pronunciation for a word intended for world-wide use, particularly evident if English-speaking and German-speaking petrographers, geologists, and geophysicists have to use it in viva voce discussions. One conceivable way to avoid such trouble in international debate on the different theories of the earth's basic shells and magmas would be to replace " tholeiite " by " palatinite ", the obsolete name coined by Laspeyres (1867) but re-defined as a basalt that is olivine-free in both norm and mode.

Harvard Department of Geology,

Reginald A. Daly.

CAMBRIDGE, MASSACHUSETTS.

15 th December, 1951.

\title{
AGE OF THE PORTSALON CONGLOMERATE
}

SIR,-It is not quite clear what bearing Mr. Andrew's remarks (Geological Magazine, pp. 441-2) have on the question of a Torridon or Devonian date for the patch of red sediments and conglomerates near Portsalon. Either formation could equally well show sedimentary contact with and infiltration into an underlying metamorphosed quartzite of presumed pre-Torridon age. - Mr. Andrews refers to the Geological Survey's early dating as based on " the very "Old Red' look of the sediments". No doubt this was the case; it seems to have been taken for granted without any particular comment in the records of the Geological Survey in Dublin.

There is in fact a noticeable difference between some of the Portsalon conglomerates and those of known Old Red, Carboniferous, and Triassic age elsewhere in Ireland :- the strong development of chloritic minerals in the matrix between the pebbles near Portsalon. (The writer exhibited a specimen of this rock at a meeting of the Geological Society in 1947.) This circumstance, as well as its geographical position, suggests that the possibility of a Torridonian age for this very isolated outlier should not be excluded. The nearest outcrops of Devonian rocks known to me are probably those at Fintona or Pomeroy in $\mathbf{N}$. Ireland, over 50 miles from Portsalon and nearly as far from it as the Torridonian in Islay.

I have not had the opportunity of making a direct comparison between the Portsalon rock and the nearest Torridonian; but it may well be that the metamorphic grade would give a clue to the age of these relatively undisturbed rocks of similar facies.

\section{Government of CyPrus, \\ Grological Survey Department, CYPRUS. \\ 31 st December, 1951.}

